\title{
The Legislation Function of the Papua People Assembly in Papua Special Autonomy
}

\author{
Decky Wospakrik \\ Faculty of Law, Cenderawasih University, Jayapura, West Papua
}

\begin{abstract}
Papua's special autonomy is an important part its implementation in the form of roles and functions by the MRP. The presence of the MRP is the mandate of the law and the present Agencies with the aim of Otsus, and in its membership consist of a wide variety of indigenous territories as a form of partiality to the indigenous people for protection policies that favour. View of the construction of the norm, role as representative institutions in the implementation of frontier by the laws the invitation by assign the role of MRP in particular just as representative institusins and supervision and does not have the function of legislation. The function of legislation in the making of the regulation is not found on the MRP, giving restrictions in the exercise of the function of legislation which only give consent against Perdasus and MRP can not be proposing regulation specifically.
\end{abstract}

Keywords : Majelis Rakyat Papua (MRP), Role and Function

DOI: $10.7176 / \mathrm{JLPG} / 100-12$

Publication date:August $31^{\text {st }} 2020$

\section{Introduction}

Article 18 of the 1945 Constitution provides an illustration that the size and extent of autonomous regions and the relationship of authority between the Central Government and Regional Governments are limited by avoiding autonomous regions becoming states within the state. Furthermore, it is said that the formation of autonomous regions in the context of decentralization in Indonesia requires the following characteristics: ${ }^{1}$

1. An autonomous region does not have sovereignty or semi-sovereignty like a federation

2. Decentralization is manifested in the formation of autonomous regions and the form of handover or recognition of governance given to regions

3. Submission or recognition of government affairs related to regulating and managing the interests of the local community in accordance with community initiatives and aspirations.

Bagir Manan explained that the articles resulting from the second amendment to the 1945 Constitution contain principles. One of the principles is the principle of recognizing and respecting special and special regional governments (article 18 paragraph 1) referred to as "special in nature" is the original government or the bumiputra government. In the practice of administering blood government, there are special areas, such as the special region of Yogyakarta and special areas, such as the special capital city area. In article 18B, special words have a broader scope, among others, because it is possible to form regional governments with special autonomy (Aceh and Papua).

The Law on Special Autonomy for the Special Regions of Aceh and Irian Jaya, in accordance with the mandate of MPR Decree No. IV / MPR / 1999 regarding GBHM 1999-2004. In line with the spirit of decentralization and broad regional autonomy, a law on Papua Province has been enacted which guarantees the implementation of special autonomy.

The principle of regional autonomy adopted still guarantees pluralism between regions and demands of initiative from below or from each region to carry out government and development functions. In fact, the arrangement that gave the Province of Irian Jaya special autonomy and which later changed to the Province of Papua reflected that under the concept of the unitary state of the republic of Indonesia it was possible to have pluralist regulatory patterns such as Papua. ${ }^{3}$

\section{Research Methods}

This study uses a normative juridical approach which prioritizes the approach of statutory regulations, namely the Papua Special Autonomy Law, Law Number 35 of 2008 concerning Amendments to Law Number 21 of 2001 concerning Papua Special Autonomy. The type of legal research used is doctrinal legal research or normative legal research, which looks at the laws and regulations that have proper norms in the analysis of power sharing in coalitions of political parties supporting the government in the presidential system in Indonesia. This research approach uses doctinal legal research, with the approach used is a statutory approach (statute-approach) and a conceptual approach (conceptual approach). ${ }^{4}$

\footnotetext{
${ }^{1}$ Krishna dan Umbu Rauta, Otonomi Daerah Perkembangan Pemikiran dan Pengaturan, Citra Aditya Bakti, Bandung, 2003, hal . 9

${ }^{2}$ Utang Rosidin, Otonomi Daerah dan Disentralisasi, Pustaka Setia, Bandung, 2010, hal 36

${ }^{3}$ Jimly Asshidiqie, Konstitusi dan konstitusionalisme Indonesia, Sinar Grafika, Jakarta, 2010, hal. 231

${ }^{4}$ Peter Mahmud Marzuki, (2005), Penelitian Hukum, Cetakan Pertama, Jakarta, Kencana, Hal. 93-95
} 


\section{Discussion}

According to Clarke and Stewart, the model of the relationship between the central government and local government can be divided into three, namely:

First, The Relative Autonomy Model. Providing relatively great freedom to local governments while respecting the existence of the central government. The emphasis is on granting freedom of action to local governments within the framework of powers / duties and responsibilities that have been formulated by laws and regulations. Second, The Agency Model. The model in which the local government does not have significant power so that its existence is seen more as an agent of the central government in charge of carrying out its central government policies. Because in this model various detailed instructions in the legislation as a control mechanism are very prominent. Third, The Interaction Model. Is a form of model where the existence and local government is determined by the interactions that occur between the central government and local governments. ${ }^{1}$

In the dynamism of the form of the Unitary State of the Republic of Indonesia based on the provisions of Article 18, 18A and Article 18B of the 1945 Constitution, first, it is possible to make arrangements that are fedearalistic in the relationship between the central government and regional governments. Second, in the dynamics of the relationship between the center and the regions, it is also possible to develop a pluralist autonomy policy, in the sense that different autonomy patterns are applied to each region. This diversity of relationship patterns has been proven by the acceptance of the principle of special autonomy for the NAD Province and Papua Province, both of which have different government institutional formats from other regional governments in general. $^{2}$

The principle of regional autonomy that has been adopted still guarantees inter-regional pluralism and demands for initiatives from below or from each region to carry out government and development functions. In fact, the regulations that gave special autonomy status to the Province of Irian Jaya (Papua), namely Law Number 21 of 2001 concerning Special Autonomy for Papua and which later changed to the Province of Papua reflect that under the concept of the unitary state of the Republic of Indonesia it is still possible pluralist regulatory patterns such as Papua.

The Papua Provincial Government consists of the Papua People's Representative Council (DPRP) as the legislative body, and the Provincial Government as the executive body. In the context of implementing Special Autonomy in Papua Province, the Papuan People's Assembly (MRP) was formed which is a cultural representation of indigenous Papuans who have certain authority in the framework of protecting the rights of indigenous Papuans, based on respect for customs and culture, empowering women, and strengthening religious harmony. Membership and the number of members of the MRP are determined by the Perdasus. The membership period for the MRP is 5 years. The MRP has the duties and powers, which are regulated by the Perdasus, among others: to provide considerations and approval to the candidates for Governor and Deputy Governor proposed by the DPRP; and give consideration and approval to the Draft Perdasus submitted by the DPRP together with the Governor. Special Regional Regulations (Perdasus) are drawn up and stipulated by the DPRP together with the Governor with consideration and approval from the MRP. Provincial Regulation (Perdasi) is the Regional Regulation of the Papua Province in the context of exercising the authority as regulated in statutory regulations. Perdasi is made and determined by the DPRP together with the Governor. ${ }^{4}$

The MRP's most central role is to protect the rights of indigenous Papuans. This role is placed in the MRP in providing protection for indigenous Papuans in various aspects of life and especially in protecting customary customary rights from being lost with the development of the dynamics of life in development in Papua as a whole. The MRP, which is positioned as a protection agency for indigenous Papuans, also plays a role in receiving complaints and aspirations from the community. The aspirations and complaints that the MRP receives from the public are complaints against local government policies. Here the MRP is involved in providing what is happening and involved in the problem solving process. Thus the MRP has a greater role in overseeing the implementation of Papua's Special Autonomy. This supervisory function is more prominent in the MRP than the function of forming and making laws and regulations, especially the Perdasus at the provincial level.

The position of the MRP in the legislative role is given a portion in terms of giving consideration and approval to a draft perdasus submitted by the DPRP and regional governments. The MRP's authority is regulated in Article 20 letter c and Article 29 paragraph (1) of the Papua Special Autonomy Law. By only being given a role in giving consideration and approval to perdasus, the MRP does not have a legislative function.

In PP No.54 of 2004 concerning MRP, in the duties and powers of the MRP, Article 36 letter b and Article 38 do not give the MRP a position in carrying out its legislative functions. This is seen in Perdasus No. 4 of 2004

\footnotetext{
${ }^{1}$ Ni’ Matul Huda, Problematika Pembatalan Peraturan Daerah, UII Press, 2010, , hal. 24

${ }^{2}$ Jimly Asshidiqie, Konstitusi dan konstitusionalisme Indonesia, Sinar Grafika, Jakarta, 2010, hal. 223

${ }^{3}$ Jimly Asshidiqie, Konstitusi, Ibid, hal. 231

${ }^{4}$ Riris Katharina, dkk, 2012, Kebijakan dan Implementasi Otonomi Khusus di Papua dan Aceh, Pusat Pengkajian, Pengolahan Data dan Informasi (P3DI) Sekretariat Jenderal DPR Republik Indonesia
} 
concerning the implementation of MRP duties and authorities in Article 2 are the same as the regulations above.

The legislative function contained in the MRP is limited to discussing the draft legislation, ratifying and giving approval to the draft Perdasus. It can be said that MRP only has a legislative function in 2 (two) forms, namely discussion of the draft law (law making process) and approval of the ratification of the draft law (law enactment approval). If you pay attention to the legislative function, according to Jimly Asshidiqie's opinion, the MRP cannot be said to have a legislative function. This is because in the legislative function it must be seen as a whole, namely starting from the process of making, submitting and ratifying it can be carried out by the MRP. As long as this role is not contained in the MRP, the MRP does not have a complete legislative function in the formation of the Perdasus. Seeing the role and function of the MRP in the Special Autonomy Law, where the MRP as a partner of the DPRP and the Regional Government in terms of regional regulations regulates something specifically for Papua Province. It does not appear that the MRP had a greater role in the formation of the Perdasus. In the Special Autonomy Law, the role of the MRP can be seen in Article 20 paragraph (1) letters $\mathrm{f}$ and $\mathrm{g}$ and Article 8 paragraph (1) letter f, while in local government Article 14 letter g. In these articles, it appears that the authority to formulate and propose a special regulation rests with the DPRP and the Regional Government.

\section{Conclusions}

By looking at the regulations governing representative institutions in the regions, it is clear that the role of the MRP in the legislative function or in terms of making perdasus regulations is not specifically seen in the regulations. In the Special Autonomy Law to the Perdasus which regulates the legislative authority of the MRP, it does not provide any room for this. the legislative powers held by the MRP. Seeing the position in planning and making legislation, the MRP only provides considerations and suggests and approves, while in the formation of regional political legislation, regional policies are carried out by the DPRP and the governor. On the other hand, there are differences in the role of the MRP in terms of the institution which has the function of a representative and supervisory agency. In both cases the role of the MRP is very clear as a function of the system of checks and balances against local governments. The regulation that gives the MRP space also clearly gives a portion to the MRP in carrying out supervision of the implementation of regional government in the era of Papua's Special Autonomy in providing protection for indigenous Papuans.

Thus there is power in the legislative function which is delegated to the MRP, specifically the formation of a Perdasus in accordance with the mandate of the Special Autonomy Law. This is intended to divide the formation of laws and regulations in Papua, where the formation of the Perdasus lies with the MRP while the formation of the Perdasi regulations lies with the DPRP.

\section{References}

Krishna dan Umbu Rauta, Otonomi Daerah Perkembangan Pemikiran dan Pengaturan, Citra Aditya Bakti, Bandung, 2003

Riris Katharina, dkk, 2012, Kebijakan dan Implementasi Otonomi Khusus di Papua dan Aceh, Pusat Pengkajian, Pengolahan Data dan Informasi (P3DI) Sekretariat Jenderal DPR Republik Indonesia

Utang Rosidin, Otonomi Daerah dan Disentralisasi, Pustaka Setia, Bandung, 2010

Ni’ Matul Huda, Problematika Pembatalan Peraturan Daerah, UII Press, 2010

Peter Mahmud Marzuki, Penelitian Hukum, Jakarta, Kencana, 2005

Undang-Undang Dasar NRI 1945

Undan-Undang Nomor 21 Tahun 2001 tentang Otonomi Khusus Bagi Provinsi Papua

Peraturan Pemerintah Nomor.54 Tahun 2004 Tentang Majelis Rakyat Papua

Peraturab Daerah Khusus Nomor 4 Tahun 2004 Tentang Pelaksanaan Tugas Dan Wewenang Majelis Rakyat Papua 